\title{
Protection on the Copyright of Network Music Works
}

\author{
Congyun Zheng and Zhiqiang Yin \\ Scientific Research Office, Jiangxi University of Technology
}

Keywords: Music works; Copyright of network music; Legal remedy.

\begin{abstract}
With the popularity and rapid development of Internet around the world, communication and download of network music works have become a new consumption hot spot. Development of digital network technology has brought users with convenience, which changes the employment ways of music works fundamentally. From another perspective, it damages the interest of copyright owners of music works including authors, performers and record companies. This new communicative way as well as the infringement has become a whole new subject for legal protection of music works' copyright. In the paper, based on legal law of copyright, it analyzes the legal positions and responsibility of infringement of network service provider as well as network users combined with representative judicial cases. It proposes some suggestions for the adjustment of legal system and authorization mechanism of music copyright with a comparative analysis on the legislative situations of music copyright protection home and abroad.
\end{abstract}

\section{Introduction}

The development of digital and network information technology has deeply changed people's life. Mr. Eric Smith, president of International Intellectual Property Alliance once said that recreational software, film industry, television and video industry, music and recording industries are are valuable national fortunes, which are sources of American global competitiveness as well. With the rapid development of networking economy, various traditional industries have been extended constantly under network environment with emergence of many emerging industries such as search engine, while music industry is right the representative. Digital music products have been combined with network technology invisibly, which has changed the single-way communication of traditional music products; meanwhile, communication of digital music works under networking environment has also presented an interactive characteristic.

Music can be recorded, transmitted and sold by personal computer and network rapidly and cheaply without being supported by large economic entity, which overthrew the traditional music industry based on record company with recording entities. Thus, today's music industry is faced with dangers, such as pirates, MP3 and rapid communication of other networking music and other recreational forms, all of which has brought a series of problems for music copyright. The formlessness of digital music products have reduced the cost greatly for massive production of music works, storage cost and demands for equipment; besides, it simplified the communication section of music works. Therefore, costs for production and transaction of legal digital music works during networking music communication can be lowered. However, due to the low cost, infringement of copyright has also been enhanced. At the same time, although websites of search engine service, P2P software system service do not provide illegal digital music works, services offered by these websites have make communication of illegal digital music works more convenient. The 
combination of $\mathrm{P} 2 \mathrm{P}$ software and intangible digital music works has endowed common individual users with the capability of copying digital music works massively and spreading the music products to nonspecific public for the first time under networking environment, which injects new element into networking music works. With all these new technologies, protection on the copyright of traditional music works has become even more difficult.

Under this circumstance, how to protect the creators' rights for music works comprehensively so as to realize the interests of obligees, stimulation of creators as well as promotion of the whole music industry has become the emphasis of the copyright field. At present, new technologies have brought a series of problems for music copyright protection, attracting wide attention from home and abroad; however, seldom study has been conducted on the protection and adjustment of copyright by taking music copyright as a single research object; Therefore, copyright protection for networking music works has been selected as the subject in this paper, trying to propose a certain effective legal mode which is suitable for our national conditions. I hope to provide certain references for the establishment of effective legal protection system for networking music works.

In this paper, infringement of networking copyright is studied comprehensively under the prescription of legal rules with comparative analysis on related legal system and related cases home and abroad by ways of conclusion, deduction and case study.

\section{New problems of copyright protection on music works under network environment}

Music is a mobile art of time, hearing and performance. Music can only be felt by singing and performance so as to product artistic effect. Music works can also be combined with other arts to generate new artistic forms. Songs can be produced by the combination of music and language; opera can be produced by the combination of music and drama; dance drama can be produced by the combination of music and dance; and film music can be formed by the combination of film art. As artistic creation, music works mainly exist in the form of various forms. Music works can be dramatic as part of drama works, or non-dramatic as a single and independent music work. Generally, there are two kinds of music works, that is, pure music and music with words. As for pure music, it is a music form widely accepted by people. While whether music works should cover words or not is controversial in many countries.

With the development of digital progress and emergence of new technology, protection on music works' copyright under traditional mode has become weaker and powerless. Besides, rapid network communication and information globalization have impacted current copyright protection system. In the world of network, people can enjoy and acquire music works for free, and they have an increasingly higher demand for music works. During the peak period, Napster website once possessed over 70 million users with over one million online users at the same time. These new technologies and applications come out from time to time, which makes copyright protection more difficult. There are mainly the following problems.

During the compression and production of MP3 music, although some voice beyond frequency may be deleted, it is only conversion of program fundamentally, which is similar to digitization. Therefore, it still belongs to illegal copy of copyright without essential change to the music contents or creation of some original music works. If agreement is not obtained from copyright owner or other obligees before processing MP3 technology, then it infringes the copyright of obligee.

If someone uploads music works of MP3 form to network without permission from music producer, then he may infringe the exclusive right of network communication of copyright owner. 
If networking MP3 music is downloaded by users to their own computers or players, copy will be formed on private reservoir, which belongs to copy to some extent. However, if upload and usage of MP3 music is only for personal study and appreciation without any business goal, then it is in the rational usage. Otherwise, copyright owner's right of reproduction may be infringed with certain legal responsibility.

Under the networking environment, usage related to MP3 music is frequent. More time, spirit as well as cost may be required for definition and legal protection of those illegal behaviors, which is beyond individual's capability compared to single copyright owner. Therefore, out of consideration of the costs, copyright owners may give up the complaint for infringement of their music works. That's why copyright of network music works can't be effectively protected.

\section{The position of provider for network service during the communication of network music works}

Provider of network service can provide technical support for the normal operation of network, and meanwhile it can also provide mass information for Internet. At the same time, provider of network service can also provide users with the most comprehensive news by collection, edition and publication so that users can fully enjoy the convenience and fun brought by network. In a sense, it is provider of network service who pushes forward the operation and development of network.

As for the position of network service provider in the communication of network music works, different countries have different rules. According to some scholars in our country, ISP has inevitably undertaken the responsibility of organization, selection and processing of information gradually, which is more and more similar to the traditional publishers. Besides, previous publishers have also begun interested in electronic publication by Internet with an undoubted position of publisher. However, some scholars in Taiwan hold different opinions. They thought punishment should be done to those Internet Service Providers who conduct illegal copy; besides, punishment should be made to those who participate in the modification and edition of information contents even if they knew they are illegal already. Traditional publishers issue works after copying them, while ISP put information on the Internet for public access. They are nearly of the same function. Thus, it is universally known that ISP is generally of the same position of traditional publisher.

ICP can control their contents on the Internet pages; while users can only download and browse information provided on the Internet without the ability of changing them. Therefore, the position of ICP is similar to traditional publisher. They should undertake the responsibility of infringement if they do not over overlook the management and review of information. On the contrary, IAP can't control information communicated on the Internet, so they won't become direct subjects of obligation. But AP needs to undertake the responsibility of infringement if they do not take any measures when copyright owner's right is infringed. Thus, the essence of the responsibility belongs to a third-party responsibility.

\section{Principles of imputation for illegal behaviors of network service provider}

A scientific classification of network infringement behaviors is determined by principles of imputation for network service providers; and meanwhile it has a decisive effect on constitutive requirements of network service provider's responsibility as well as the establishment of burden of proof rules, which affects the design of liability exemption and contestable clause directly. At the 
same time, it also provides basis for the formation of principles and methods of damage compensations for network service providers. Therefore, principles of liability imputation determine the effect of liability system for network service providers to great extents.

Here are several principles to determine whether network service provider needs to undertake the responsibility of infringement.

Principle of non-fault liability. According to this opinion, network service provider is the gainer of information communication. They should undertake the responsibility if infringement information is spread with medium offered by network service provider. Strict principles of liability were once been established in America.

Principle of liability for fault. This principle takes actor's subjective fault as the main factor of liability. Only if network service provider conducts illegal behavior subjectively that he will be investigated and affixed legal liability. With the adoption of fault liability principle, it can not only protect the interests of infringer, but it can also guarantee the development of network service provider as well as information industry.

Doctrines of fault presumption. The doctrine of fault presumption means that the party must undertake civil responsibility unless he can prove he is innocent during lawsuit. Since it is difficult for victims to reveal network service provider's subjective fault while the latter has absolute advantages in investigation and evidence collection as well as evidence storage, it is good for guaranteeing the victim's interest to put evidence by network service provider, which can also standardize their service behaviors to some degree.

We should treat network service provider's liability for tort carefully and differently. As for the liability for tort of provider of network access service, liability of fault principle should be adopted. Strict liability principle was once set by legislation in America, and it has been applied to many countries. As a matter of fact, application of no-fault liability can strengthen the burden of network service provider to great extent, and it can even affect normal development of the whole industry. If network access service provider can prove their innocence or legal obligation, then their liability for tort can be exempted. However, for network content provider, their liability for tort shall be determined by the doctrine of fault presumption responsibility since the information they provide can be controlled to some degree. Therefore, they should undertake certain responsibility and some damages. Although network works are required to be previewed by offers, the liability of network content provider still needs to be fulfilled without exemption.

\section{The establishment of legal protection system for copyright of music works under network environment}

The balance of interest is the value realized by law. All contents of copyright law are considered to be balanced. That is, the interest of copyright owner should be kept balanced with the user's need. As the basic principle of copyright law, principle of balanced interest is the manifestation of basic spirit of modern intellectual property law, which has been widely recognized by judicial practice home and abroad. Legal problems brought by digital technology have been standard domestically and internationally. Although it may have some mistakes or deviation, digital copyright law has emerged and been mature gradually. Copyright law earns new birth in digital time instead of dying away. 
A perfect legal protection system for copyright law is beneficial for coordinating the relationship among music copyright owner, network service provider and personal user so as to promote a balanced interest of digital copyright.

In China, deficiencies of legal protection for network information communication are mainly manifested in the following aspects. First, current legislation is mainly restricted to administrative management of network subject, which pays more attention to administrative intervention while less attention to protection of individual rights; second, liability for tort of network service provider lacks principles and standards without corresponding legal basis for the range and conditions of liability that service provider should undertake; third, liability for copyright owner with search and chain service is lack of clear descriptions, which is not beneficial for the implementation of network service and protection of legal rights; fourth, there is no unified standard for the compensation of network communication infringement, so it is bad for the protection of copyright owner's interest. The deficiencies above are not only bad for the legal protection of intellectual property, but they are also bad for a sound development of network information industry.

There are two ways for copyright owners to realize or protect their copyright on the Internet. They may perform their rights by themselves or entrust others to help them to realize. By analyzing current situation and fact of music works' copyright protection under network environment, we find that practical sales of $\mathrm{CD}$, tapes and discs may decrease a lot if there are many copies of music works, that is, consumers' desire for purchasing original music works may decrease, which will directly affect the interest of copyright owner. With the increase of copies, the interest of copyright owner has also lost a lot. Meanwhile, illegal copy can also affect social welfare. Due to the large illegal copy of music works, social welfare can be increased in a short time, but it may impact people's spiritual creation undoubtedly in a long time since the rights and interests of creator can't be protected.

The increase of gaining for network illegal copier is at the price of less interest of copyright owner. According to principle of modern economics, if some one affects others' welfare without paying or earning, then the externality comes out. If the influence is bad, then it is called negative externality; if this influence is beneficial, then it is called positive externality. With the development of network, such harmful copy is hard to be controlled because Internet is virtual with mass infringement behaviors. Therefore, illegal copiers can't be found out for punishment out of consideration of individual copyright owner. If a collective administrative system can be established for network copyright, then these cases can be handed over to collective administrative organization, which can improve current situation a lot. Thus, establishment of collective administrative organization for network copyright is beneficial for the growth of social welfare. Based on these reasons, it is of extreme importance for the existence of collective administrative organization for copyright.

While providing convenience for the protection of copyright owner, collective administration system of copyright can also offer convenience for the communication and employment of works. The most obvious advantage of collective administration system for network music copyright is that it can reduce the transaction cost of copyright and promote the efficiency of using music works and recording works under network environment. Obviously, collective administration system is an effective way to protect copyright of music works, so its establishment should be enhanced.

At present, our country has strengthened network communication and protection of digital music works by collective administrative organization of copyright so as to solve the following problems. 
An official collective administrative institute should be established for network music copyright. As is mentioned before, a collective administrative institute for copyright with certain monopoly position possesses powerful strength to protect the interest of music copyright owner.

Coordination between copyright owner and music collective administrative organization shall be strengthened so that copyright owner can fully recognize the advantages of collective administrative institute; and meanwhile his interest during network communication for music works can be realized by these organizations.

Special institutes for rights protection should be established for collective administrative organization of music copyright with equipment of professional staff. Once illegal infringement has been found, measures should be adopted timely. If necessary, lawsuit can also be used to crack on pirate network music and illegal sharing behaviors. However, action by collective administrative organization for music copyright is far from enough.

Rational cost standard should be formulated by collective administrative organization for music copyright with effective authorized channels. By far, in order to promote a successful transition of music consumption from free usage to paid usage, the charge standard should take full consideration of common groups regarding their acceptability. Meanwhile, the time, place and kinds of authorized rights should also be considered comprehensively when formulating charging standards. At the same time, as for authorized channels, collective administrative organization should make efforts from establishing professional website, smooth application access and fast authorized ways.

\section{Conclusions}

The emergence of digital technology has brought earth-shaking changes to people's life and production, which deeply affects people's life and survival ways all over the world. However, emergence and employment of this new technology has impacted copyright system greatly, which is far deeper and more comprehensive than any time before digital age; besides, such influence is extremely obvious in the field of music copyright. Music copyright is a relatively complicated field of copyright protection system, which involves interests of many bodies, such as creator of music, producer and issuer of music works as well as performers. With the development of digital networking technology, the subject of right, object of right as well as item contents have all changed a lot. Meanwhile, digital networking technology has also brought challenges for modern music industry with new communication ways and employment ways. For example, popularization and application of digital networking technologies such as MP3 technology and P2P technology have seriously threatened the interests of music copyright owners, which contribute to a sharp contradiction between music producer and user. How to protect the copyright of network music works? How to determine the definition of rational usage? And how to coordinate the relationship among music copyright owner, network service provider and network user? These are all problems needing to be solved. In the paper, it mainly analyzes the positions and liabilities of network service provider and network user in the communication of network music works, and meanwhile it analyzes the establishment of legal protection system for music works under network environment, exploring a comprehensive, effective and rational legal protection system for network music works from legal remedy, establishment of collective administrative system and legal protection of technological measures. The research and conclusion may be shallow, but I sincerely hope my study can contribute a little to the perfection of related legislation. 


\section{References}

[1] Encyclopedia of China. (Volumes of Music and Dance) Beijing. Press of Encyclopedia of China. 1989.

[2] Meng Xiangjuan. Identification of Copyright Infringement. Beijing. Law Press China, 2000:1819.

[3] Shen Xiaolei. Study on Several Issues of Copyright for Music Works【M】. Theories of Civil and Commercial Laws, the 12th volume. Beijing, Law Press China. 1999:31.

[41 [Japanese] Laws of Copyright, translated by Wei Qixue. Chapter 50 M]Beijing, Law Press China. 1990:101-102.

[5][Japanese] Intellectual Property in Market Competition, translated by Liao Zhengheng, Jinlu, et al. 【M】, Beijing, Commercial Press. 2000:41.

[6] Zhou Xiaobing. The Trial Frontiers【M】 . Beijing, Press Law China, 2004:9.

[7] Zouzhi, Sunyan. Conservation Regulations on the Rights of Network Information Communication by Cases【M】 Beijing, Press Law China. 2008:187.

[81Jiang Zhipei. Laws of Internet and Electronic Commerce (revised edition)【M】Beijing, Press Law China. 2002:182.

[9] Guo Weihua, Jin Chaohu, Wangjing. Legal Problems and Countermeasures of Network 【M】.Beijing, Press Law China. 2001:61-62.

[101Wang Limin, Study on the Laws of Electronic Commerce[M].Beijing, China Legal Publishing House. 2002:184. 